\title{
Simulation of High Viscosity Gas-Liquid Two-Phase Flow in a Horizontal Mini Pipe
}

\author{
SUKAMTA
}

\begin{abstract}
Two-phase flow is used in many industries such as nuclear reactors, boilers, condensers, liquefactions of natural gas, etc. Two-phase flow is a flow in a pipe which has two states of fluid such as solid-liquid, liquid-gas, gas-solid. In a twophase flow, there are three channels, namely vertical, horizontal and inclined channels. In the horizontal channel, the most widely found flow is the flow patterns of stratified flow, bubble flow, plug flow, stratified wavy flow, annular flow, and slug flow. Refer to the previous research above, the flow patterns were mostly obtained by using an experimental study. The advantage of using the simulation is the ability to predict the flow pattern and pressure gradient before doing the experimental study so it can be known earlier if it will have an insecure flow pattern, i.e. slug flow. This research was conducted to find the flow pattern and pressure gradient by using a Computational Fluid Dynamics (CFD) software, the Ansys Fluent 19.0 Student. The model which was used is the Volume of Fluid (VOF) with the fluid of air-water and glycerin (40\%-70\%). The length of the pipe was $200 \mathrm{~mm}$, the inner diameter was $1.6 \mathrm{~mm}$, and the length of the test section was $100 \mathrm{~mm}$. Liquid superficial speeds $\left(\mathrm{J}_{\mathrm{L}}\right)$ of $0.033 \mathrm{~m} / \mathrm{s} ; 0.149 \mathrm{~m} / \mathrm{s} ; 0.232 \mathrm{~m} / \mathrm{s} ; 0.539$ $\mathrm{m} / \mathrm{s} ; 0.7 \mathrm{~m} / \mathrm{s} ; 2.297 \mathrm{~m} / \mathrm{s}$ and $4.935 \mathrm{~m} / \mathrm{s}$ were used, while the air superficial speed $\left(\mathrm{J}_{\mathrm{G}}\right)$ was $9.62 \mathrm{~m} / \mathrm{s}$. The result of the simulation showed slug annular and churn flow patterns. Slug annular was formed at $\mathrm{J}_{\mathrm{L}}=0.033 \mathrm{~m} / \mathrm{s} ; 0.149 \mathrm{~m} / \mathrm{s}$ and $0.232 \mathrm{~m} / \mathrm{s}$ with the glycerin content of $40 \%$ and $50 \%$. Slug annular pattern was formed when the glycerin content was $60 \%$ and $70 \%$ with $\mathrm{J}_{\mathrm{L}}=0.539 \mathrm{~m} / \mathrm{s}$. Viscosity affects the flow pattern, the higher the glycerin content, the higher the viscosity and the more fluid than air. The higher the $\mathrm{J}_{\mathrm{L}}$ and glycerin content, the higher the pressure gradient.
\end{abstract}

Keywords: Glycerine, gas-liquid, pressure gradient, simulation, two-phase flow.

\section{INTRODUCTION}

Two-phase flow is used in many industries such as a nuclear reactors, boilers, condensers, liquefactions of natural gas, etc. In the phenomenon of fluid flow, there are two kinds of flow, namely one-phase flow and two-phase flow. One-phase flow is a flow in a pipe that has one state of fluid (gas or liquid). Two-phase flow is a flow in a pipe which has two states of fluid such as solid-liquid, liquid-gas, and gassolid. The simulation to analyze this flow is CFD (Computational Fluid Dynamics) that analyzes and calculates the fluid flow process. The data will be more accurate and save time to calculate the result of the fluid analysis by using CFD. CFD not only produces the data but also moving flow images, graph calculation results and types of simulations such as velocity, pressure, mass flow, etc. CFD has many choices that can be used as needed such as Solid, Fluent, etc. The fluid flow simulation could use the Fluent because it is specialized to analyze a flow and can simulate it.

Researches about the flow pattern in the capillary pipe have already been studied (Sudarja, Indarto, Deendarlianto, \& Haq, 2016). They studied the flow pattern of two-phase flow of gas-liquid in a mini pipe and horizontal flow where the inner pipe diameter was $1.6 \mathrm{~mm}$. Its result showed bubbly, slug, churn, slugannular, wavy annular and annular flow patterns. The study used experimental method while this study used the CFD simulation method which had never been used before. They also conducted research about the characteristics of the pressure gradient in the two-phase flow of air-liquid mixture and $20 \%$ glycerin in a mini horizontal pipe. The result showed that the higher the superficial gas velocity and the superficial water velocity, the greater the pressure gradient. Previous research (Sukamta, 2019) studied the CFD simulation of 
a liquid-air annular flow in the direction of a horizontal pipe with the inner pipe diameter of $1.9 \mathrm{~mm}$. This research revealed that the flow pattern is not constant, depending on $\mathrm{J}_{\mathrm{G}}$ and $\mathrm{J}_{\mathrm{L}}$, and the time of the data collection. The longer the time, the more perfect the annular flow which was produced. The increase of the $\mathrm{J}_{\mathrm{G}}$ will cause a higher wave and less liquid flew at the upper part of the pipe.

Meanwhile, Korawan (2015) studied a twophase flow (liquid-air) in a horizontal pipe with the variation of the liquid superficial velocity. The result of the research was the flow pattern being bubble and Stratified. Wibowo et al. (2015) researched the experimental study about the subs of the stratified flow pattern of two phases flowing in the same direction based on the fluctuations of the pressure difference in a horizontal pipe. A stratified flow pattern was observed. It was done by a direct visual observation, and the area was divided into subs, namely stratified smooth, two-dimensional wave, roll wave and atomization. Gunawan et al. (2015) conducted an experimental study about pressure fluctuation and interface shear stress of a liquid-air stratified flow in a horizontal pipe. The flow pattern was found being stratified smooth and the Pressure gradient will be larger if $\mathrm{J}_{\mathrm{G}}$ and $\mathrm{J}_{\mathrm{L}}$ are also larger. Khaledi et al. (2014) studied the a twophase flow, holding fluid and the decreasing pressure in a thick oil-gas flow. The result showed stratified, stratified wavy, bubbly flow, plug flow, roll-wave, and slug flow flow patterns.

Tsaoulidis et al. (2013) studied the flow pattern and the decrease of two-phase ionic fluid pressure of liquid-water in a microchannel. The result showed that the flow pattern are plug flow, disturbed plug, plug \& drop train flow, intermittent flow, dispersed flow, quasi annular flow, throat annular flow, rivulet annular flow, drop flow and irregular flow. Chinnov et al. (2016) conducted research about a two-phase flow pattern on short horizontal rectangular microchannels. The result of this research was the flow patterns being bubble, annular, jet, stratified and churn regimes. Saisorn and Wongwises (2008) studied the flow pattern, hollow fraction, and the two-phase pressure decrease of air-water in a horizontal circular microchannel. The result of this research was the flow patterns being slug flow, throatannular flow, churn flow, and annular-rivulet flow.
Based on the previous researches above, the flow patterns were mostly obtained by using experimental study, and the flow patterns mostly are stratified, plug, slug, annular and bubble. The research which is studied has the same variables with the previous study but different method and concentration of glycerin. This research studied the flow pattern of airwater and glycerin (40\%-70\%) in a horizontal capillary pipe using a CFD simulation method of the Volume of Fluid (VOF). The CFD simulation of this research used Ansys Fluent 19 Student with a pipe diameter of $1,6 \mathrm{~mm}$ and the of $J_{G}=9.62 \mathrm{~m} / \mathrm{s}$ and the variation of $J_{L}=$ 0.033 - $4.935 \mathrm{~m} / \mathrm{s}$ which have never been studied before.

\section{RESEARCH METHOD}

There are three processes in the CFD simulation, namely pre-processing, processing and post-processing. Pre-processing is the first stage in the research analysis with CFD simulation. In this stage, the generation of geometry or computational domain in the using Computer-Aided Design (CAD) in a 2D or 3D form was conducted. The generation of geometry can be done in the CFD software or by using Special CAD drawing software such as Inventor or Solidworks for complex geometry formation. The processing stage is the calculation phase of a simulation. In this stage, the parameter given in the pre-processing stage will be calculated repeatedly or called by iteration. For the horizontal two-phase flow of air-liquid in a pipe, the two-phase multiplier was determined based on the formula used by $\mathrm{Xu}$, et.al (1998) as follows :

$$
\Phi_{1}^{2}=\frac{\Delta \mathrm{P}_{\mathrm{TP}}^{\mathrm{F}}}{\Delta \mathrm{P}_{\mathrm{L}}^{\mathrm{F}}}=\frac{\rho_{1} \Delta \mathrm{P}_{\mathrm{TP}}^{\mathrm{F}}}{2 \mathrm{f}_{1}[\mathrm{G}(1-\mathrm{x})]^{2} \mathrm{~N}}
$$

The calculation will finish if the calculation results have reached a predetermined level of accuracy or have reached the limit of the number of predetermined iterations. Postprocessing is the last stage of the simulation. In this stage, retrieval, and processing of data in the form of magnitudes for certain variables, graphics, and visualization in the form of contours and animations. Similarly, at the mesh generating stage, the post-processing stage can be done on the CFD software or using other special post-processing software. 
Geometry and mesh. Geometry drawing in 2D or $3 \mathrm{D}$ for the sims of CFD can be assisted by the use of some software, such as Fluent, Inventor, AutoCAD, Solid work, etc. After creating the geometry, the file is imported into the same format as Ansys Fluent. The geometry that is used in this research was a $2 \mathrm{D}$ drawing with the inner pipe diameter of $1.6 \mathrm{~mm}$, pipe length of $200 \mathrm{~mm}$, and a test section length of $100 \mathrm{~mm}$ and total obtained data in 0.2 seconds. The geometry of pipe model can be seen in Figure 1.

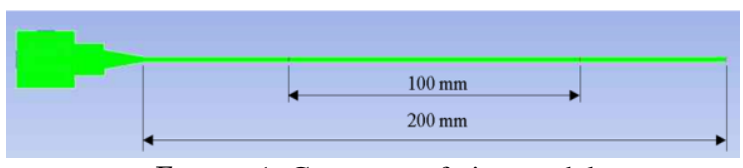

FIGURE 1. Geometry of pipe model

After making the geometry, it is necessary to do the meshing process, then it can be analyzed in a CFD program. It should be noted that the mesh size contained in an object will affect the accuracy and computational power of the analysis. The smaller or finer the mesh, the more accurate the results will be obtained. However, it requires greater computing power. After the meshing process is complete, then a mesh quality check is carried out with a report quality. The result of mesh can be seen in Figure 2.

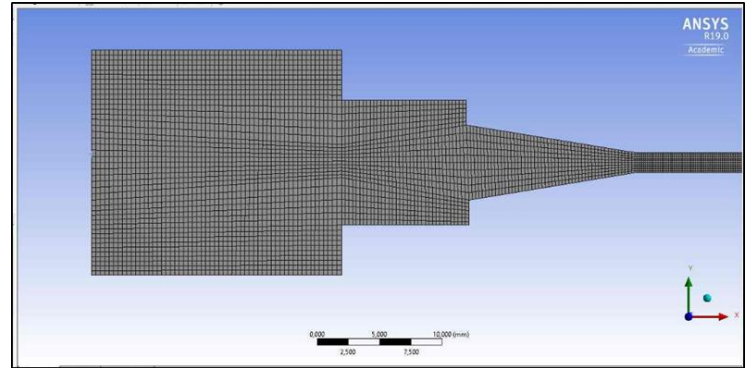

FIGURE 2. Result of mesh

\section{RESULT AND DISCUSSION}

1. Liquid flow pattern $+40 \%$ glycerin with superficial air velocity $\left(\mathrm{J}_{\mathrm{G}}\right) 9.62 \mathrm{~m} / \mathrm{s}$ and various superficial liquid velocities $\left(\mathrm{J}_{\mathrm{L}}\right)$.

Table 1 in the variation of $\mathrm{J}_{\mathrm{L}}=0.033 \mathrm{~m} / \mathrm{s}$ shows the annular slug flow pattern which is characterized by the presence of fluid that attached to the bottom of the pipe. This phenomenon occurs because of the superficial small water velocity so, the liquid is less than the air. Also, the liquid is attached to the bottom of the pipe because of the influence of the gravity and density of the liquid which is more substantial than the air. Therefore, the liquid is at the bottom of the pipe.

TABLE 1. Liquid flow pattern $+40 \%$ glycerine with $\mathrm{J}_{\mathrm{G}}=9.62 \mathrm{~m} / \mathrm{s}$ and $\mathrm{J}_{\mathrm{L}}=0.033 \mathrm{~m} / \mathrm{s} ; 0.149 \mathrm{~m} / \mathrm{s} ; 0.232 \mathrm{~m} / \mathrm{s} ; 0.539$

\begin{tabular}{|c|c|c|}
\hline $\mathrm{J}_{\mathrm{L}}(\mathrm{m} / \mathrm{s})$ & Figure & $\begin{array}{l}\text { Flow } \\
\text { Pattern }\end{array}$ \\
\hline 0.033 & Streamline $\longrightarrow$ & $\begin{array}{l}\text { Slug } \\
\text { Annular }\end{array}$ \\
\hline 0.149 & 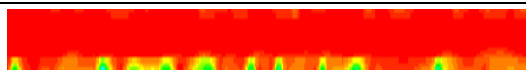 & $\begin{array}{l}\text { Slug } \\
\text { Annular }\end{array}$ \\
\hline 0.232 & $=$ & $\begin{array}{c}\text { Slug } \\
\text { Annular }\end{array}$ \\
\hline 0.539 & Dine & Churn \\
\hline 0.7 & 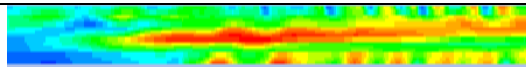 & Churn \\
\hline 2.297 & 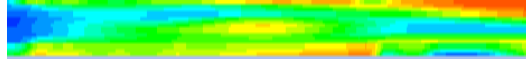 & Churn \\
\hline 4.935 & 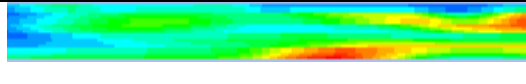 & Churn \\
\hline
\end{tabular}

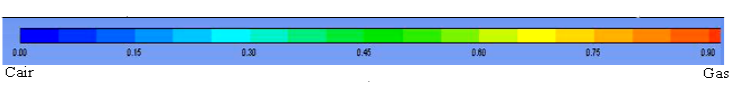


2. Liquid-air flow pattern $+50 \%$ glycerin with superficial air velocity $\left(\mathrm{J}_{\mathrm{G}}\right) 9.62 \mathrm{~m} / \mathrm{s}$ and the superficial liquid velocity $\left(\mathrm{J}_{\mathrm{L}}\right)$ that varies.

Table 2 shows the annular slug flow pattern on $\mathrm{J}_{\mathrm{L}}=0.033 \mathrm{~m} / \mathrm{s} ; 0.149 \mathrm{~m} / \mathrm{s}$ and $0.232 \mathrm{~m} / \mathrm{s}$. In table 4.2 with $\mathrm{J}_{\mathrm{L}}=0.033 \mathrm{~m} / \mathrm{s}$, it is seen that the annular slug flow pattern formed is less than $\mathrm{J}_{\mathrm{L}}=0.149 \mathrm{~m} / \mathrm{s}$ and $0.232 \mathrm{~m} / \mathrm{s}$. This happens because the superficial liquid velocity $\left(\mathrm{J}_{\mathrm{L}}\right)$ is slower then, the annular slug flow pattern that is formed is less. For $\mathrm{J}_{\mathrm{L}}=$ $0.539 \mathrm{~m} / \mathrm{s} ; 0.7 \mathrm{~m} / \mathrm{s} ; 2.297 \mathrm{~m} / \mathrm{s}$ and $4.935 \mathrm{~m} / \mathrm{s}$ show the churn flow pattern because there is a disturbance in the flow in the form of air then, the flow pattern is formed randomly. At $\mathrm{J}_{\mathrm{L}}=4.935 \mathrm{~m} / \mathrm{s}$, it can be seen that the pattern of the churn flow is more dominated by blue and green.

3. Liquid-air flow pattern $+60 \%$ glycerin with superficial air velocity $\left(J_{G}\right) 9.62 \mathrm{~m} / \mathrm{s}$ and superficial velocity of water $\left(\mathrm{J}_{\mathrm{L}}\right)$ that varies.

From table 3, slug annular flow pattern occurs in $\mathrm{J}_{\mathrm{L}}=0.033 \mathrm{~m} / \mathrm{s} ; 0.149 \mathrm{~m} / \mathrm{s} ; 0.232$ $\mathrm{m} / \mathrm{s}$ and $0.539 \mathrm{~m} / \mathrm{s}$. Slug annular flow pattern still occurs in $\mathrm{J}_{\mathrm{L}}=0.539 \mathrm{~m} / \mathrm{s}$. This thing occurs because the percentage of glycerin was different. The percentage of glycerin affects the viscosity and superficial liquid velocity $\left(\mathrm{J}_{\mathrm{L}}\right)$. The higher the percentage of glycerin causes the viscosity of the fluid increases so, the superficial air velocity $\left(\mathrm{J}_{\mathrm{G}}\right)$ is difficult to penetrate the fluid. It causes the flow pattern that occurs is more dominated by fluid flow.

4. Liquid flow pattern $+70 \%$ glycerin with superficial air velocity $\left(\mathrm{J}_{\mathrm{G}}\right) 9.62 \mathrm{~m} / \mathrm{s}$ and superficial liquid velocity $\left(\mathrm{J}_{\mathrm{L}}\right)$ that varies.

Based on table 4, many annular slug flow patterns more occur in the percentage of $70 \%$ glycerin than $60 \%$ glycerin. This is caused by the effect of viscosity on $70 \%$ glycerin is greater than $60 \%$. As a consequence, the liquid is thicker and more difficult to be passed by air, and the massperiod on $70 \%$ glycerin is greater than $60 \%$ glycerin. Therefore, the annular slug flow pattern occurs more.

TABLE 2. Liquid flow pattern $+50 \%$ glycerin with $\mathrm{J}_{\mathrm{G}}=9.62 \mathrm{~m} / \mathrm{s}$ and $\mathrm{J}_{\mathrm{L}}=0.033 \mathrm{~m} / \mathrm{s} ; 0.149 \mathrm{~m} / \mathrm{s} ; 0.232 \mathrm{~m} / \mathrm{s} ; 0.539$ $\mathrm{m} / \mathrm{s} ; 0.7 \mathrm{~m} / \mathrm{s} ; 2.297 \mathrm{~m} / \mathrm{s}$ and $4.935 \mathrm{~m} / \mathrm{s}$. (Please rearrange this table such that it will not be separated by column

\begin{tabular}{|c|c|c|}
\hline $\begin{array}{c}\mathrm{J}_{\mathrm{L}} \\
(\mathrm{m} / \mathrm{s})\end{array}$ & Figure & Flow Pattern \\
\hline 0.033 & Insuren & $\begin{array}{c}\text { Slug } \\
\text { Annular }\end{array}$ \\
\hline 0.149 & 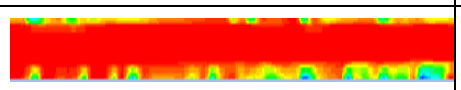 & $\begin{array}{c}\text { Slug } \\
\text { Annular }\end{array}$ \\
\hline 0.232 & Mnse- & $\begin{array}{c}\text { Slug } \\
\text { Annular }\end{array}$ \\
\hline 0.539 & 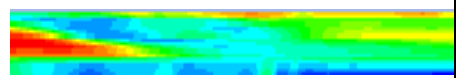 & Churn \\
\hline 0.7 & 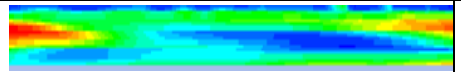 & Churn \\
\hline 2.297 & 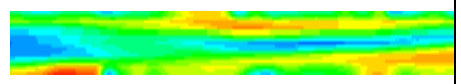 & Churn \\
\hline 4.935 & 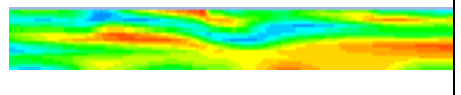 & Churn \\
\hline
\end{tabular}

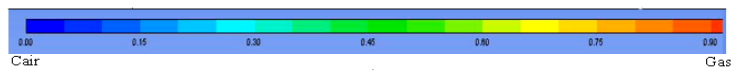


TABLE 3. liquid flow patterns $+60 \%$ glycerin with $\mathrm{J}_{\mathrm{G}}=9.62 \mathrm{~m} / \mathrm{s}$ and $\mathrm{J}_{\mathrm{L}}=0.033 \mathrm{~m} / \mathrm{s} ; 0.149 \mathrm{~m} / \mathrm{s} ; 0.232 \mathrm{~m} / \mathrm{s} ; 0.539$

\begin{tabular}{|c|c|c|}
\multicolumn{2}{|c}{$\mathrm{m} / \mathrm{s} ; 0.7 \mathrm{~m} / \mathrm{s} ; 2.297 \mathrm{~m} / \mathrm{s}$ and $4.935 \mathrm{~m} / \mathrm{s}}$. \\
\hline $\mathrm{J}_{\mathrm{L}}(\mathrm{m} / \mathrm{s})$ & Figure & $\begin{array}{c}\text { Flow } \\
\text { Pattern }\end{array}$ \\
\hline 0.033 & $\begin{array}{c}\text { Slug } \\
\text { Annular }\end{array}$ \\
\hline 0.149 & & $\begin{array}{c}\text { Slug } \\
\text { Annular }\end{array}$ \\
\hline 0.232 & $\begin{array}{c}\text { Slug } \\
\text { Annular }\end{array}$ \\
\hline 0.539 & & $\begin{array}{c}\text { Slug } \\
\text { Annular }\end{array}$ \\
\hline 0.7 & & Churn \\
\hline 2.297 & & Churn \\
\hline 4.935 & & Churn \\
\hline
\end{tabular}

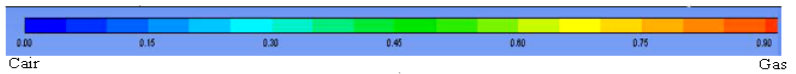

TABLE 4 . Liquid flow patterns $+70 \%$ glycerin with JG $=9.62 \mathrm{~m} / \mathrm{s}$ and JL $=0.033 \mathrm{~m} / \mathrm{s} ; 0.149 \mathrm{~m} / \mathrm{s} ; 0.232 \mathrm{~m} / \mathrm{s} ; 0.539$

\begin{tabular}{|c|c|c|}
\multicolumn{2}{|c}{$\mathrm{m} / \mathrm{s} ; 0.7 \mathrm{~m} / \mathrm{s} ; 2,297 \mathrm{~m} / \mathrm{s}$ and $4.935 \mathrm{~m} / \mathrm{s}}$. \\
\hline $\mathrm{J}_{\mathrm{L}}(\mathrm{m} / \mathrm{s})$ & Figure & $\begin{array}{c}\text { Flow } \\
\text { Pattern }\end{array}$ \\
\hline 0.033 & $\begin{array}{c}\text { Slug } \\
\text { Annular }\end{array}$ \\
\hline 0.149 & & $\begin{array}{c}\text { Slug } \\
\text { Annular }\end{array}$ \\
\hline 0.232 & & $\begin{array}{c}\text { Slug } \\
\text { Annular }\end{array}$ \\
\hline 0.539 & Slug \\
& Annular \\
\hline 0.7 & & Churn \\
\hline 2.297 & & Churn \\
\hline 4.935 & & Churn \\
\hline
\end{tabular}

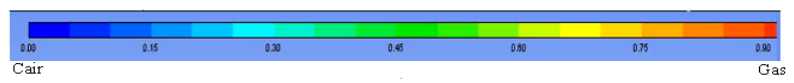


5. The relationship between superficial liquid velocity $\left(\mathrm{J}_{\mathrm{L}}\right)$ varies with the pressure gradient of $J_{G}=9.62 \mathrm{~m} / \mathrm{s}$ and the glycerin percentage of $40 \%, 50 \%, 60 \%$, and $70 \%$ as seen in figure 3.

6. The relationship between superficial liquid velocity $\left(\mathrm{J}_{\mathrm{L}}\right)$ varies with the pressure gradient of $J_{\mathrm{G}}=9.62 \mathrm{~m} / \mathrm{s}$ and the glycerin percentage of $40 \%, 50 \%, 60 \%$, and $70 \%$.

Figure 4 shows the increase in every glycerin percentage. This phenomenon occurs because the percentage of glycerin is increasing then, it affects the fluid viscosity and the pressure gradient. The rise of fluid viscosity makes the pressure gradient increases then, the graphics increase in every glycerin percentage. In figure 5 , it can be seen that the more $\mathrm{J}_{\mathrm{L}}$, the more the pressure gradient.

Previous studies (Sukamta et.al, 2016) have also investigated air-water flow simulations for horizontal pipes. The use of water and air is used to determine changes in flow characteristics. In this study, acrylic pipes with a diameter of $19 \mathrm{~mm}$ and a length of $1000 \mathrm{~mm}$ were used. Fukano et al., (Fukano et.al, 1993) have also examined the characteristics of twophase flow of water in capillary pipes with diameters of $1 \mathrm{~mm}, 2.4 \mathrm{~mm}, 4.9 \mathrm{~mm}$ and $9 \mathrm{~mm}$, and the direction of vertical upward, horizontal and vertical flow. down. The results of the study show that capillary force is important in the case of pipes with a diameter of $5 \mathrm{~mm}-9$ $\mathrm{mm}$ and the flow pattern does not have a significant change according to the direction of flow. Meanwhile, studies on numerical modeling and experimental investigations of gas-liquid forming slugs at $\mathrm{T}$-junction microchannel with a hydraulic diameter of $113 \mu \mathrm{m}$ and superficial water velocities $0 / .042$ - $0.757 \mathrm{~m} / \mathrm{s}$ and $0.018-0.791 \mathrm{~m} / \mathrm{s}$ were carried out (Santos et.al, 2010). The modeling used was CFD with Fluent software. From the research, two flow patterns can be observed; slug and annular flow patterns. The result of the comparison between numerical and experimental modeling is that the slug flow is $400 \mu \mathrm{m}$ shorter. Differentiation may be caused by fluid oscillations resulting from changes in pressure captured in the numerical model.

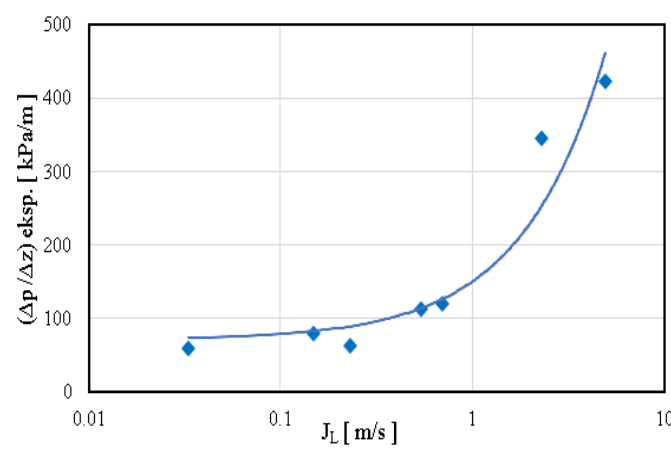

(a)

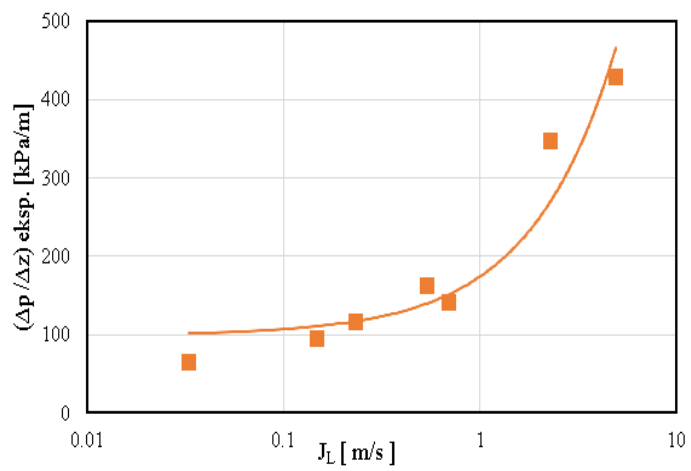

(b)

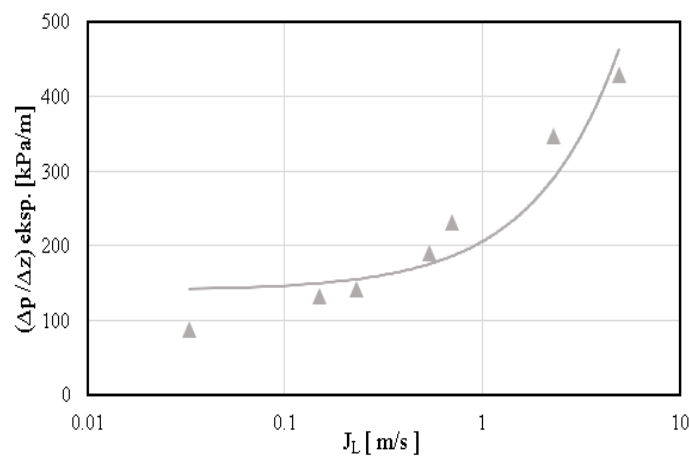

(c)

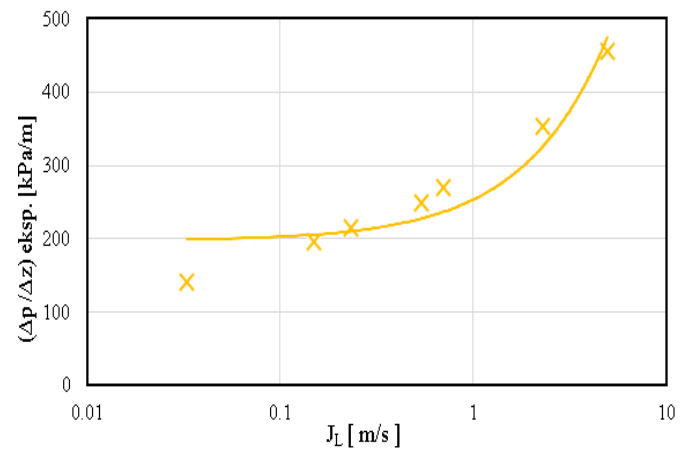

(d)

FIGURE 3. The graphic on the relationship between superficial liquid velocity $\left(\mathrm{J}_{\mathrm{L}}\right)$ varies with the pressure gradient of $\mathrm{J}_{\mathrm{G}}=9.62 \mathrm{~m} / \mathrm{s}$ and the glycerin percentage (a) 40\%, (b) 505, (c) $60 \%$ and (d) $70 \%$. 


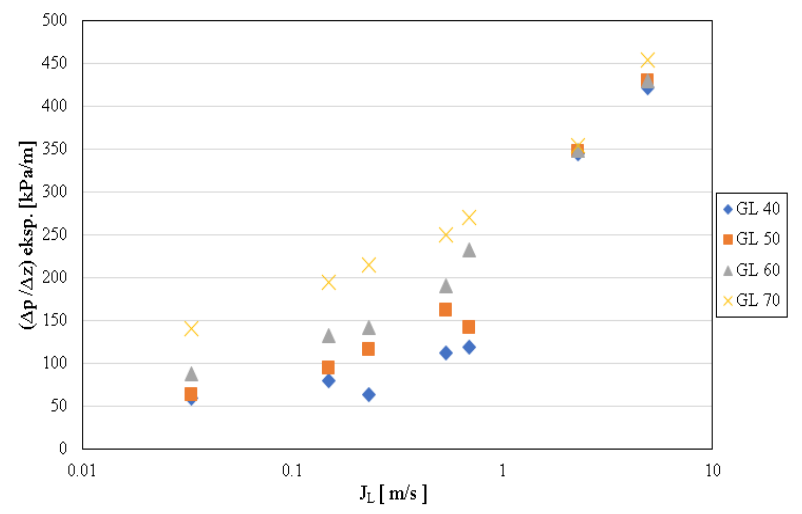

FIGURE 4. Graphic on the relationship between superficial liquid velocity $\left(\mathrm{J}_{\mathrm{L}}\right)$ varies with the pressure gradient of $\mathrm{J}_{\mathrm{G}}=9.62 \mathrm{~m} / \mathrm{s}$ and the glycerin percentage of $40 \%, 505,60 \%$ and $70 \%$

\section{CONCLUSION}

We summarize the main contributions of the research that the flow pattern is the slug annular and churns. The Slug annular is formed at $\mathrm{J}_{\mathrm{L}}=$ $0.033 \mathrm{~m} / \mathrm{s} ; 0.149 \mathrm{~m} / \mathrm{s}$ and $0.232 \mathrm{~m} / \mathrm{s}$ and the glycerin percentage of $40 \%$ and $50 \%$. However, at the glycerin percentage of $60 \%$ and $70 \%$ with $\mathrm{J}_{\mathrm{L}}=0.539 \mathrm{~m} / \mathrm{s}$ still can be seen in the presence of a slug annular flow pattern. It is caused by the greater influence of viscosity on glycerin. It also makes the air difficult to pass the fluids because of the high level of viscosity. Viscosity affects the flow pattern; the more glycerin percentage, the more viscosity level occurs. Therefore, the pressure gradient will be increasing. The increase of pressure gradient affects the percentage of liquid on the fluid pattern. The greater the $\mathrm{J}_{\mathrm{L}}$ and the glycerin percentage, the greater the pressure gradient can be obtained.

\section{ACKNOWLEDGMENT}

Thanks for the Ministry of Research, Technology, and the Higher Education Republic of Indonesia for the Research Funds on the scheme of PDUPT. I want to express my gratitude for Gilang Gita Pranata and Sudarja for measuring and analyzing data.

\section{REFERENCES}

Chinnov, E. A., Ron'shin, F. V., \& Kabov, O. A. (2016). Two-Phase Flow Patterns In Short Horizontal Rectangular Microchannels. International Journal of Multiphase Flow, 80, 57-68.
Fukano, T., and Kariyasaki, A. (1993). Characteristics of gas-liquid two-phase flow in a capillary tube. Nuclear Engineering and Design, 141(1-2), 5968.

Gunawan, D., Hudaya, A. Z., \& Indarto. (2015). Studi Eksperimen Mengenai Fluktuasi Tekanan dan Tegangan Geser Antarmuka Pada Aliran Stratified Air Udara Pada Pipa Horizontal. Jurnal Teknik Mesin dan Industri, Fakultas Teknik, Universitas Gadjah Mada, 32-40.

Khaledi, H. A., Smith, I. E., Unander, T. E., \& Nossen, J. (2014). Investigation Of TwoPhase Flow Pattern, Liquid Holdup, and Pressure Drop-In Viscous Oil-Gas Flow. International Journal of Multiphase Flow, 37-51.

Korawan, \& Dwi, A. (2015). Pola Aliran Dua Fase (Air-Udara) Pada Pipa Horizontal Dengan Variasi Kecepatan Supervisial Air. Jurnal Teknik Mesin, Sekolah Tinggi Teknologi Renggolawe, 57-63.

Saisorn, S., \& Wongwises, S. (2008). Flow Pattern, Void Fraction And Pressure Drop Of Two-Phase Air-Water Flow In A Horizontal Circular Microchannel. Experimental Thermal and Fluid Science, 748-760.

Santos, Rafael M. and Masahiro Kawaji. (2010). Numerical modeling and experimental investigation of gas-liquid slug formation in a microchannel $\mathrm{T}$ junction. International Journal of Multiphase Flow, 36(4),314-323

Sudarja, Indarto, Deendarlianto, \& Haq, A. (2016). Experimental study on the void 
fraction of air-water two-phase flow in a horizontal circular mini channel. AIP Conference Proceedings, 1737. https://doi.org/10.1063/1.4949302

Sukamta Sukamta, Thoharudin Thoharudin, Dedy Melianto Nugroho. (2016). Simulasi CFD Aliran Stratified AirUdara Searah Pada Pipa Horisontal. 1-8.

Sukamta, S. (2019). Computational Fluid Dynamics ( CFD ) and Experimental study of Two-Phase Flow Patterns GasLiquid with Low Viscosity in a Horizontal Capillary Pipe. 8(8), 16-23.

Tsaoulidis, D., Dore, V., Angeli, P., Plechkova, N. V., \& Seddon, K. R. (2013). Flow Patterns and Pressure Drop Of Ionic Liquid-Water Two-Phase Flow In Microchannels. International Journal of Multiphase Flow, 1-10.

Wibowo, R., Hudaya, A. Z., \& Kabib, M. (2015). Studi Eksperimen Mengenai SubSub Pola Aliran Strarified Pada Aliran Dua Fasa Searah Berdasarkan Fluktuasi Beda Tekanan Pada Pipa Horizontal. Jurnal Simetris, Universitas Muria Kudus, 385-380.

Xu, G. P., Tou, K. W., C. P. (1988). Two-hase Void Fraction and Pressure Drop in Horisontal Cross FlowAccros a Tube Bundle. International Journal of Fluid Engineering, 120, 140-145.

PENULIS:

\section{Sukamta}

Department of Mechanical Engineering, Faculty of Engineering, Universitas Muhammadiyah Yogyakarta, Jl. Brawijaya, Tamantirto, Kasihan, Bantul, Yogyakarta 55183, Indonesia

Email : sukamta@umy.ac.id 